\title{
Determining Students' Learning Outcomes in Basic Education: A Proposed CPD for Teachers
}

\author{
Cecilia Junio-Sabio, Monaliza M. Manalo, and Florinda G. Vigonte
}

\begin{abstract}
This paper concerns the learning outcomes of the students' in basic education in the subjects Science and Mathematics as a basis for a proposed Continuing Professional Development (CPD) for teachers in Diliman Elementary School (DES) in the Philippines. It employs document analysis of the Mean Percentage Score (MPS) of the National Achievement Test results for a five-year period from 2013-2018. Results show that learning outcomes in Science per Grade/Level is increasing as reflected by their mean of $78.82,80.22,81.01,81.71,81.92$, and 82.30 respectively but per school year, the result was generally declining. For Mathematics, learning outcomes vary. It can be noted that there is an increase in performance for Grades I, II, IV and V. However, learning performance for Grades III and VI decreases. As per School Year (SY), learning outcomes in Mathematics reported a diminishing pattern, aggregate performance decreases as the year progresses. It can be safely concluded from the results of the study that learning outcomes in basic curriculum is declining as time advances. A Continuing Professional Development (CPD) Plan was proposed and highly recommended for implementation.
\end{abstract}

Index Terms-Basic education, continuing professional development (CPD), learning outcomes, teachers.

\section{INTRODUCTION}

According to Bayocot (2014) [1], teachers have certain duties and responsibilities to perform that support the vision and mission of the Department of Education. He posited that the core objective of any educational system is to promote teaching-learning process; therefore, the main accountability of teachers is to facilitate learning process. Teachers are honored and expected to act in a manner deserving of public trust because of their important role in education. "With learners at the center, teaching serves as the most important means of awakening and nurturing the learners' interest and learning potentials."

Teachers should see themselves as capable of achieving the dimensions of good teaching to be able to achieve effective teaching and productive learning. Classroom teachers think about a balance teaching activities in the classroom with crucial professional upgrading activities.

Manuscript received August 12, 2019; revised November 23, 2019. This work was supported in part by Bulacan State University, Department of Education, and Local Government Officials of Municipality of San Rafael, Bulacan, 3008 Philippines.

C. J. Sabio is with the Graduate School, De La Salle Araneta University and University of the City of Manila, Philippines (e-mail: vpcfjs@gmail.com).

M. M. Manalo is with the Department of Education. She is now with the Diliman Elementary School, Philippines (e-mail: monalizammanalo27@gmail.com).

F. G. Vigonte is with the Bulacan State University, Philippines (e-mail: florvigonte@yahoo.com).
They also think which skills to teach, what teaching strategies to use, what enrichment activities and what learning experiences to provide.

It is widely recognized that "effective teachers constitute a valuable human resource for schools - one that needs to be treasured and supported" (Darling Hammond, 2013, p. 7) [2]. Like the members of other professions, teachers and education support staff need to be constant learners who see their own learning as being primary to membership of the profession rather than something that is incidental or optional. Udani (2012) [3] opined that Continuing Professional Education (CPE) in one's profession is indicative of a person's genuine concern for his present and future work.

According to Porter et al, (2013) [4] the content of teachers' professional development included targeting improvements to content knowledge, pedagogical strategies, alignment of curriculum and assessment, and a range of other topics. Similarly, Borko's (2004) [5] description of the myriad of contexts for teacher learning makes obvious the challenges of identifying and measuring teacher learning:

For teachers, learning occurs in many different aspects of practice, including their classrooms, their school communities, and professional development courses or workshops. It can occur in a brief hallway conversation with a colleague, or after school when counseling a troubled child. To understand teacher learning, we must study it within these multiple contexts, taking into account both the individual teacher-learners and the social systems in which they are participants. (p.4)

Stages of development

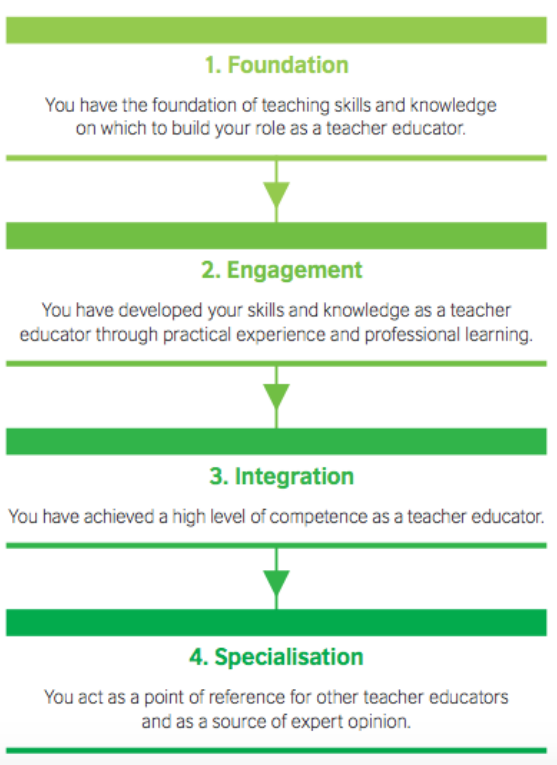

Fig. 1. CPD framework for teacher educators [6]. 
The British Council (2017), published a Continuing Professional Development (CPD) Framework for teacher educators. The main substance of the publication includes the stages of development, professional practices, enabling skills and self-awareness features. There are four stages of development which includes foundation, engagement, integration and specialisation. Foundation includes knowledge of the subject matter and teaching skills. Engagement refers to the developed skills through practical experience. Integration is characterized by high level of confidence being a teacher educator. Lastly, specialization is described as being a source of expert opinion. The present study operated on these four stages of development set by the British Council. CPD once anchored on this framework, the true essence of professional development may be maximized. Fig. 1 depicts the theoretical framework of this study.

Fig. 1 shows the research paradigm which serves as a guide to the professional development of all those involved in the education and training of teachers.

In the Philippines, Section 2 of the "Philippine Teachers Professional Act of 1994", provides for the policy of the State to regulate and professionalize the practice of teaching, to wit:

"The State recognizes the vital role of the teachers in nation-building and development through a responsible and literate citizenry. Towards this end, the State shall ensure and promote quality education by proper supervision and regulation of the licensure examination and professionalization of the practice of the teaching profession" [7]

Later on, Republic Act (R.A.) No. 10912 or the "CPD Act of 2016" was enacted. It promotes and upgrades the practice of the profession in the country and institute measures that will continuously improve the competence of the professionals in accordance with the international standards of practices, thereby, ensuring their contribution in uplifting the general welfare, economic growth and development of the nation [8].

The terms staff development, in-service, and professional development are often used interchangeably, and professional development is used to describe all of these categories of training. Professional development focuses on knowledge, skills, and attitudes required of teachers, administrators, and other school employees that are directed toward all students learning at high levels of achievement (McClure 2014 [9]).

Nevertheless, students learning at high levels of achievement seems questionable due to the alarming decline in students' learning outcomes. In an article by Ronda (2011) [10] he stated that according to DepEd, the students' achievement rates in the Basic Education are declining. Education Secretary Armin Luistro [11] spoke about this matter during the National Education Summit held at the Shangri-La Hotel in Makati. The purpose of the education summit is to give education stakeholders the state of basic education, higher education and technical-vocational education in the country. He presented graphs showing a downward trend representing achievement levels and survival rates of elementary and high school students. The graphs were part of his report on the state of basic education at the National Education Summit. Based on National Achievement Tests (NAT) results from 2005 to 2010, DepEd records showed a declining achievement level of elementary and high school students. NAT results of high school students from 2005 to 2010 showed that the mean percentage score (MPS) of students dropped from school year 2007-08, which posted an MPS of 49.26 percent, to 47.40 percent in 2008-09, and down to 46.30 percent in 2009 to 2010.

For the elementary achievement test results, negligible gains were made with low MPS results of 64.81 percent in $2007-08,66.33$ percent in 2008 to 2009 , and 69.21 percent in 2009 to 2010 .

\section{A. Statement of the Problem}

Specifically, this study aimed to answer the following research questions: 1). What is the learning outcomes of the learners in basic education from the past 5 years in Science and Mathematics: (a.) per Grade/Level? (b.) per School year?

2). What Continuing Professional Education for teachers may be proposed to enhance students' learning outcomes?

\section{METHOD}

\section{A. Research Design}

This study employed the descriptive quantitative research design. It focuses on the learning status of the students by quantifying their learning outcomes through their performance in the National Achievement Test in Science and Mathematics. Document analysis was utilized in determining such learning outcomes.

\section{B. Participants}

Elementary pupils of Diliman Elementary School SY 2018-2019 were the respondents.

\section{Instrument}

Students' Learning Outcomes per Grade/Level and per School Year (SY) were taken from the School Consolidated Test Result from 2013-2018 by Mean Percentage Score (MPS). Permission were granted by the Schools' Division Superintendent, Supervisors, School Principal, teachers, parents and pupils under study.

\section{Data Gathering Procedure}

After the research ethics protocol was ensured, the researchers proceeded to look for the consolidated annual test results from Grades 1 to VI from SY 2013-2014 to SY 2017-2018. The results were recorded, compared, tabulated, and analyzed for further interpretation.

\section{E. Statistical Treatment}

Descriptive statistics are used to treat the data collected. Mean analysis was applied for the scores both in Science and Mathematics across Grade/Level and among School Years. Graphs were further utilized to show visual representation of the data collected. 


\section{RESULTS AND DisCUSSION}

A. Learning Outcomes of the Learners in Basic Education from the Past 5 Years in Science and Mathematics

TABLE I: LEARNING OUTCOMES IN SCIENCE PER CONSOLIDATED TEST Result For a 5-Year PERIOd MEASURed by MEAN PERCENTAGE SCORE (MPS) PER GRADE/LEVEL

\begin{tabular}{ccccccc}
\hline & $\mathbf{2 0 1 3 -}$ & $\mathbf{2 0 1 4}-$ & $\mathbf{2 0 1 5}-$ & $\mathbf{2 0 1 6}-$ & $\mathbf{2 0 1 7 -}$ & \\
Grade/Level & $\mathbf{2 0 1 4}$ & $\mathbf{2 0 1 5}$ & $\mathbf{2 0 1 6}$ & $\mathbf{2 0 1 7}$ & $\mathbf{2 0 1 8}$ & $\overline{\mathbf{x}}$ \\
\hline 1 & 80.00 & 79.91 & 77.75 & 78.00 & 78.44 & 78.82 \\
2 & 81.20 & 80.59 & 78.72 & 80.00 & 80.59 & 80.22 \\
3 & 82.00 & 81.63 & 80.00 & 81.00 & 80.40 & 81.01 \\
4 & 83.00 & 82.00 & 81.00 & 81.80 & 80.77 & 81.71 \\
5 & 83.90 & 82.45 & 80.90 & 81.45 & 80.90 & 81.92 \\
6 & 84.00 & 82.90 & 81.12 & 82.00 & 81.50 & 82.30 \\
\hline$\overline{\mathbf{x}}$ & $\mathbf{8 2 . 3 5}$ & $\mathbf{8 1 . 5 8}$ & $\mathbf{7 9 . 9 2}$ & $\mathbf{8 0 . 7 1}$ & $\mathbf{8 0 . 4 3}$ & $\mathbf{8 1 . 0 0}$ \\
\hline
\end{tabular}

Table I shows the Students' Learning Outcomes in Science per Consolidated Test Result for a 5-year Period 2013-2018. It can be inferred that the Mean Percentage Score (MPS) per Grade/Level is increasing. As per school years, the MPS is fluctuating but can generally be described as decreasing as seen in the decrease in MPS of 82.35 for 2013-2014 down to MPS of 80.43 for SY 2017-2018. The table exhibits the students' performance in Science subject for five school years which shows a shift in the pattern which implies that their aggregate performance decreased, slightly increased and then decreased again but generally implies poor performance as the year progresses. It further exhibits the students' performance in Science subject per Grade/Level which shows a rising pattern. This implies that their aggregate performance regardless of school years becomes satisfactory as the Grade/Level advances.

TABLE II: LEARNING OUTCOMES IN MATHEMATICS PER CONSOLIDATED Test Result for a 5-Year Period Measured By Mean Percentage

\begin{tabular}{ccccccc}
\multicolumn{7}{c}{ SCORE (MPS) PER GRADE LEVEL } \\
\hline \multirow{\text{Grade/Level}}{*}{$\mathbf{2 0 1 3 -}$} & $\mathbf{2 0 1 4}-$ & $\mathbf{2 0 1 5}-$ & $\mathbf{2 0 1 6}-$ & $\mathbf{2 0 1 7 -}$ & \\
\hline 1 & 80.20 & 79.65 & 78.88 & 79.00 & 78.12 & 79.17 \\
2 & 80.00 & 80.67 & 79.65 & 80.23 & 79.47 & 80.00 \\
3 & 81.87 & 81.04 & 80.50 & 78.90 & 77.10 & 79.88 \\
4 & 82.56 & 82.00 & 80.00 & 80.42 & 79.00 & 80.80 \\
5 & 83.00 & 82.45 & 81.00 & 80.99 & 79.60 & 81.41 \\
6 & 84.00 & 81.77 & 80.31 & 79.56 & 78.23 & 80.77 \\
\hline$\overline{\mathbf{x}}$ & $\mathbf{8 1 . 9 4}$ & $\mathbf{8 1 . 2 6}$ & $\mathbf{8 0 . 0 6}$ & $\mathbf{7 9 . 8 5}$ & $\mathbf{7 8 . 5 9}$ & $\mathbf{8 0 . 3 4}$ \\
\hline
\end{tabular}

Table II shows the Students' Learning Outcomes in Mathematics per Consolidated Test Result for a 5-year Period 2013-2018. It can be inferred that the Mean Percentage Score (MPS) per Grade/Level varies. As per school years, the MPS is constantly decreasing from 81.94 in SY 2013-2014 down to 78.59 in SY 2017-2018. It exhibits the students' performance in Mathematics subject for five school years which shows diminishing pattern regardless of school year. This means that their aggregate performance decreases as the year progresses. The table also shows the students' performance in Mathematics subject per Grade/Level with fluctuating pattern and implies that their aggregate performance either increases or decreases as the Grade/Level advances.

Fig. 2 exhibits the students' performance in Science subject for five school years which shows a fluctuation in the pattern which implies that their aggregate performance decreased, slightly increased and then decreased again.

It can be gleaned from Fig. 2 that generally, the learning outcomes in Science imply a poor performance as the year progresses.

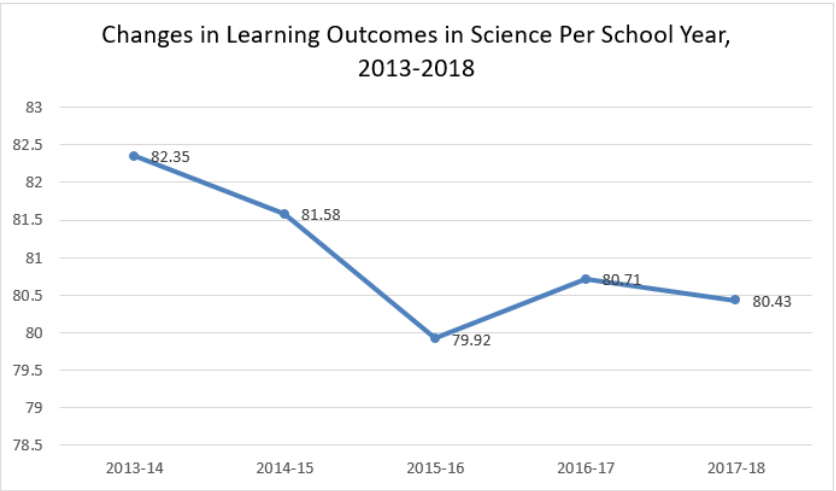

Fig. 2. Learning outcomes in science per school year.

The result gives a support to the claim of Secretary Armin Luistro (2011) that the students' achievement rates are declining as shown by the graph from the National Education Summit with a downward trend. It is also in congruence with the NAT result from 2005-2010 showing a declining achievement level of elementary students.

Fig. 3 presents the learning outcomes in Mathematics per School Year.

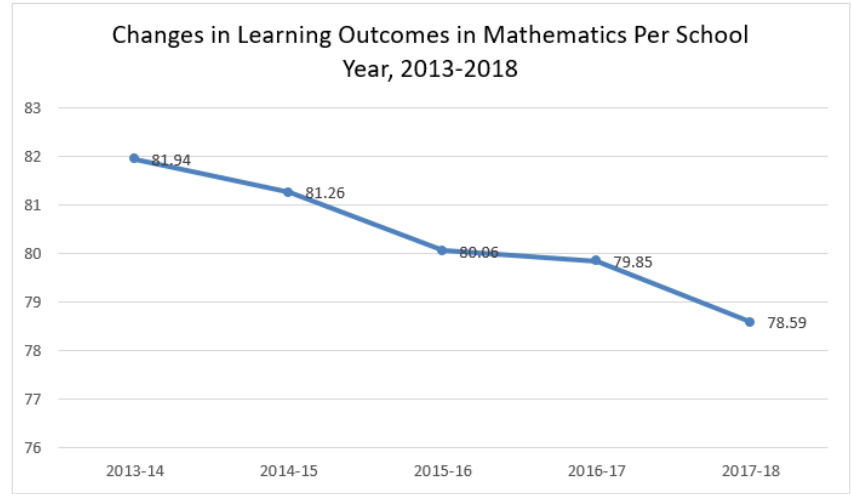

Fig. 3. Learning outcomes in mathematics per school year.

It can be inferred from Fig. 3 that the learning outcomes in Mathematics shows a diminishing pattern regardless of school year. Thus, aggregate performance decreases as the year progresses.

\section{B. What Continuing Professional Education for Teachers May Be Proposed to Enhance Students' Learning \\ Outcomes?}

Results of the study show positive learning outcomes for Science per School Year (SY) per Grade/Level. Yet, in Mathematics, it becomes poorer and poorer as time moves forward. Similarly, Grades III and Grades VI needs to be given more attention since scores decline on those particular levels. Thus, the CPDs are proposed for teachers to enhance students' learning outcomes as shown in Table III.

Table III shows the proposed Customized Training Plan for Diliman Elementary School (DES) which is deemed to be responsive to the needs, both actual and perceived, by the teacher-respondents of the study. 
TABLE III: CUSTOMIZED TRAINING PLAN FOR DILIMAN ELEMENTARY SCHOOL (DES) TEACHERS I. Course/Program Title: C.USTOMIZED TRAINING PLAN FOR DILIMAN ELEMENTARY SCHOOL (DES) TEACHERS

II. Course/Program Brief Description: The training plan is responsive: designed to cater the specific needs of DES teachers based on their given recommendations anchored on the training needs analys is conducted by the researcher.

III. Proposed PQF level: 7

IV. Particular Continuing Professional Competency/ies: Technologv, subject matter content, skills and management

\begin{tabular}{|c|c|c|c|c|c|}
\hline $\begin{array}{l}\text { Sub-Topics and Time } \\
\text { Allotment for every } \\
\text { topic }\end{array}$ & Area of CPD Activity & $\begin{array}{l}\text { Expected Learning } \\
\text { Outcomes }\end{array}$ & $\begin{array}{c}\text { Activities to } \\
\text { Achieve Learning } \\
\text { Outcomes }\end{array}$ & $\begin{array}{c}\text { Assessment } \\
\text { Strategies } \\
\text { including, } \\
\text { Assessment } \\
\text { Tools }\end{array}$ & $\begin{array}{l}\text { Requirements } \\
\text { /Outputs }\end{array}$ \\
\hline $\begin{array}{l}\text { ICT Skills for Teaching } \\
\text { (May 2019) }\end{array}$ & Professional/Ethics & $\begin{array}{l}\text { Utilize ICT skills } \\
\text { commonly used by } \\
\text { teachers like Micros oft } \\
\text { Office and completion of } \\
\text { sample online forms } \\
\text { required by DepEd. } \\
\text { Use ICT in improving } \\
\text { students' motivation } \\
\text { towards learning } \\
\text { particularly in English, } \\
\text { Science and } \\
\text { Mathematics }\end{array}$ & $\begin{array}{l}\text { Lecture-Discussion } \\
\text { Hands-on Training } \\
\text { Workshop } \\
\text { Oral Participation }\end{array}$ & Pre \& Post Test & Test Result \\
\hline $\begin{array}{l}\text { Student Discipline and } \\
\text { Behavior Problems: } \\
\text { (September 2019) }\end{array}$ & Ethics & $\begin{array}{l}\text { Identify appropriate } \\
\text { procedure in dealing } \\
\text { with students' } \\
\text { misbehaviors }\end{array}$ & $\begin{array}{l}\text { Lecture-Discussion } \\
\text { Group Activities } \\
\text { Demonstration }\end{array}$ & $\begin{array}{l}\text { Actual } \\
\text { Demenstration }\end{array}$ & $\begin{array}{l}\text { Action Plan in } \\
\text { Establishing } \\
\text { Appropriate } \\
\text { Procedure for } \\
\text { Students' } \\
\text { Misbehavior }\end{array}$ \\
\hline $\begin{array}{l}\text { School Management } \\
\text { (October 2019) }\end{array}$ & Professional & $\begin{array}{l}\text { Manage school } \\
\text { operations relevant to } \\
\text { the daily work of the } \\
\text { teachers. }\end{array}$ & $\begin{array}{l}\text { Lecture-Discussion } \\
\text { Workshop } \\
\text { Demonstration } \\
\text { Oral Participation }\end{array}$ & $\begin{array}{l}\text { Oral Reporting } \\
\text { Demonstration } \\
\text { Written Output }\end{array}$ & $\begin{array}{l}\text { Updated and } \\
\text { functional } \\
\text { Organizational } \\
\text { Chart }\end{array}$ \\
\hline $\begin{array}{l}\text { Student Counselling } \\
\text { (October 2019) }\end{array}$ & Professional & $\begin{array}{l}\text { Highlight the importance } \\
\text { of teachers as } \\
\text { counselors to their } \\
\text { students focusing on } \\
\text { improving low academic } \\
\text { performance in English, } \\
\text { Science and } \\
\text { Mathematics }\end{array}$ & $\begin{array}{l}\text { Lecture-Discussion } \\
\text { Workshop } \\
\text { Oral Participation }\end{array}$ & Pre \& Post Test & Test Result \\
\hline
\end{tabular}

VII. Financial Prajection:

A. Expected Number of Participants: 15

B. Proposed Charge per Participant: NONE. Expenses will be taken from School Mainten ance and Other Operating Expenses:

C. Relevant Details in Support of the Financial Viability of the Program

\section{CONCLUSION}

Based on the Consolidated Test Result for a 5-Year Period Measured by Mean Percentage Score (MPS) from the National Achievement Test of the Basic Education Elementary pupils, it can be safely concluded that learning outcomes in Science per grade/level gets better but generally gets poorer per school year while learning outcomes in Mathematics vary per grade/level and decrease per school year. Henceforth, schools should take into consideration improving this result by aligning their CPD efforts in improving learning outcomes of students. Teachers should therefore take appropriate steps in providing teaching-learning processes that will improve students' learning outcomes in Science and Mathematics as the ultimate test of effective teacher's performance is a positive learning outcomes of students.

\section{RECOMMENDATION}

Grounded on the findings of the study, it is highly recommended that the proposed CPD Training Plan for
Teachers be implemented.

\section{CONFLICT OF INTEREST}

"The authors declare no conflict of interest".

\section{AUTHOR CONTRIBUTIONS}

Monaliza M. Manalo conducted the research; Dr. CJ Sabio analyzed the data; Florinda G. Vigonte wrote the paper; ...; all authors had approved the final version.

\section{REFERENCES}

[1] A. Bayocot, "Balancing the teaching activities in the classroom with crucial professional upgrading activities for teachers," PPSTA Country Report, The 30th ASEAN Council of Teachers Convention. Singapore, 2014.

[2] L. Darling-Hammond, "Keeping good teachers: Why it matters, what leaders can do," Educational Leadership, vol. 60, no. 8, pp. 6-13, 2013.

[3] Z. A. Udani, "Continuing professional education: Training and developing Filipino professionalsaAmidst globalization," PASCN Discussion Paper No. 2002-02, University of Asia and the Pacific, 2002.

[4] A. C. Porter, M. S. Garet, L. M. Desimone, and B. F. Birman, "Providing effective professional development: Lessons from the 
eisenhower program," Science Educator, vol. 12, no. 1, pp. 23-40, 2003.

[5] Borko, "Professional development and teacher-learning: pMapping the Terraine," American International Research Association in Collaboration with JSTOR, 2012

[6] British Council, "Continuing professional development (CPD) framework for teacher educators," United Kingdom, 2017.

[7] R. A. 7836, Philippine Teachers Professional Act of 1994, Manila, Philippines.

[8] R. A. 10912, Continuing Professional Development (CPD) Act of 2016, Manila, Philippines.

[9] S. McClure, Qualitative Research a Guide to Design and Implementation, San Francisco, CA: Wiley \& Sons, Inc., 2014.

[10] J. T. Ronda, "Examining key concepts in research on teachers' use of mathematics curricula," Review of Educational Research, vol. 75, no. 2 , pp. 211-246, 2011.

[11] A. Luistro and J. A. Lapus. (2008). The education system facing the challenges of the 21st century country: Republic of the Philippines. [Online].

Available: http://www.ibe.unesco.org/National_Reports/ICE_2008/philippines_ NR08.pdf

Copyright $\odot 2020$ by the authors. This is an open access article distributed under the Creative Commons Attribution License which permits unrestricted use, distribution, and reproduction in any medium, provided the original work is properly cited (CC BY 4.0).

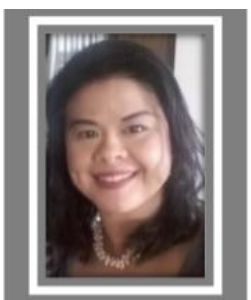

C. J. Sabio was the former vice president for Academic Affairs and held the rank of SUC vice president IV at the Pamantasan ng Lungsod ng Maynila (University of rhe City of Manila). She holds professor $\mathrm{V}$ academic rank in the same University. She has previously worked at the Commission on Higher Education (CHED), Office of the Chairman, Office of the President of the Philippines and a GOCC holding various management and executive position. She was the former Head of the Research and Industry Engagement Center of the Gulf College based in Muscat Oman which is in collaboration with Staffordshire University,
University of Reading and Hull University London, UK. She also teaches in DLSAU and PUP Graduate Schools.

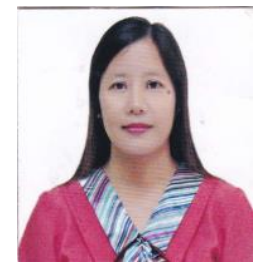

Monaliza M. Manalo is from Diliman, San Rafael, Bulacan, Philippines. She was born on April 27 1978. Currently she is pursuing the master of arts in educational major in educational administration at De La Salle Araneta University in Malabon City, Metro Manila.

She is a master teacher I at Diliman Elementary School (DES) at Diliman, San Rafael, Bulacan, Philippines. She is interested in making researches about educational management.

Mrs. Manalo is an active member of Bulacan Public School Teachers Association.

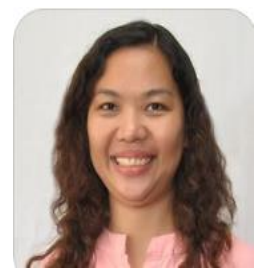

Florinda G. Vigonte is from Tambubong, San Rafael, Bulacan, Philippines 3008. Currently she is pursuing the doctor of philosophy in educational leadership and management with specialization in management research at La Consolacion University, Philippines.

She is an instructor I at Bulacan State University (BulSU), Malolos City, Bulacan, Philippines. She authored the following books: Psychology (Malabon City, Philippines: Jimczyville Publications,2015); Fundamentals of Accountancy, Business \& Management I (Malabon City, Philippines: Jo-Deh Publishing, 2016); and Accountancy, Business \& Management II (Malabon City, Philippines: Jo-Deh Publishing, 2017). After making researches about factors associated with students' academic performance, parental involvement strategies and action researches, she is also interested in making researches about educational management.

Mrs. Vigonte is the chair for the Accreditation Committee Area V (Research) of the BulSU College of Industrial Technology. Elected and served as Treasurer of the local Faculty Association Union. Recipient of Outstanding Teacher Award of Sanctuario of St. Maria Theresa School. 